\title{
Irradiation induces G2/M cell cycle arrest and apoptosis in p53-deficient lymphoblastic leukemia cells without affecting Bcl-2 and Bax expression
}

Elisabeth M.C. Strasser-Wozak ${ }^{1}$, Bernd L. Hartmann ${ }^{1}$, Stephan Geley ${ }^{1}$, Roswitha Sgonc ${ }^{1}$, Günther Böck', Antonio J. Oliveira Dos Santos ${ }^{1}$, Rosa Hattmannstorfer ${ }^{1}$, Hugo Wolf ${ }^{1}$, Margit Pavelka ${ }^{2}$ and Reinhard Kofler ${ }^{1,3}$

\footnotetext{
1 Institute for General and Experimental Pathology, Division of Molecular Pathophysiology, University of Innsbruck Medical School, A-6020, Innsbruck, Austria

2 Institute for Histology and Embryology, University of Innsbruck Medical School, A-6020, Innsbruck, Austria.

${ }^{3}$ corresponding author: Institute for General and Experimental Pathology, University of Innsbruck, Medical School, Fritz-Pregl Str. 3, A-6020 Innsbruck, AUSTRIA

tel: 0043-512-507-3102; fax:0043-512-507-2867

email: reinhard.kofler@uibk.ac.at
}

Received 6.10.97; revised 8.1.98 accepted 2.4.98

Edited by J.C. Reed

\begin{abstract}
The tumor suppressor p53 has been implicated in gamma irradiation-induced apoptosis. To investigate possible consequences of wild-type p53 loss in leukemia, we studied the effect of a single dose of gamma irradiation upon p53deficient human T-ALL (acute lymphoblastic leukemia) CCRF-CEM cells. Exposure to 3-96 Gy caused p53independent cell death in a dose and time-dependent fashion. By electron microscopic and other criteria, this cell death was classified as apoptosis. At low to intermediate levels of irradiation, apoptosis was preceded by accumulation of cells in the G2/M phase of the cell division cycle. Expression of Bcl2 and Bax were not detectably altered after irradiation. Expression of the temperature sensitive mouse p53 V135 mutant induced apoptosis on its own but only slightly increased the sensitivity of CCRF-CEM cells to gamma irradiation. Thus, in these, and perhaps other leukemia cells, a p53- and Bcl-2/Bax-independent mechanism is operative that efficiently senses irradiation effects and translates this signal into arrest in the G2/M phase of the cell cycle and subsequent apoptosis.
\end{abstract}

Keywords: p53; apoptosis; CCRF-CEM; human leukemia; cell cycle; gamma irradiation: Bcl-2; Bax; p21/WAF1

Abbreviations: ALL, acute lymphoblastic leukemia; FACS, fluorescence-activated cell sorter; FITC, fluorescein isothiocyanate; ts, temperature sensitive; PBS, phosphate buffered saline; TUNEL, terminal deoxynucleotidyl transferase-mediated dUTP nick end-labeling

\section{Introduction}

Gamma irradiation induces apoptosis in many cell types and this phenomenon has been considered to critically depend upon the product of the tumor suppressor gene p53 (Lowe et al, 1993; Clarke et al, 1993; Komarova et al, 1997) whose main biological functions are control of cell proliferation and induction of apoptosis (Lane, 1992; Canman et al, 1994; White et al, 1994; White, 1995). Gamma irradiation induces DNA damage which is a known trigger of p53 activity (Vogelstein and Kinzler, 1992). The concept that irradiation causes cell death through p53mediated apoptosis has been corroborated by studies with p53-deficient mice that showed markedly reduced sensitivity to irradiation-induced cell death in various cell types (Lowe et al, 1993; Clarke et al, 1993). Since over 50\% of human cancers are deficient in p53 (Prokocimer and Rotter, 1994; Imamura et al, 1994), the proposed dependence of irradiation-induced apoptosis upon functional p53 has considerable consequences for cancer therapy. More recently, however, evidence has been provided suggesting that gamma irradiation may also cause apoptosis through p53-independent mechanisms (Strasser et al, 1994; Bracey et al, 1995; Allday et al, 1995; MacFarlane et al, 1996). Which cells might be equipped with such mechanisms and how these two types of cell death relate to each other on a mechanistic level, is not well understood. In the present study, we investigated the effect of gamma irradiation upon the widely used human acute lymphoblastic T-cell leukemia cell line CCRFCEM (Norman and Thompson, 1977). CEM cells are compound heterozygous for the p53 mutations $\mathrm{R} 175 \mathrm{H}$ and R248Q (Cheng and Haas, 1990) that render p53 deficient in the ability to transactivate typical p53 response genes and to mediate apoptosis (Geley et al, 1997a). Hence this cell line, and stably transfected subclones thereof expressing a p53 temperature sensitive mutant, are suitable substrates for the comparison of p53-dependent and p53-independent irradiation-induced cell death forms.

\section{Results and Discussion}

Gamma irradiation induces G2/M arrest and cell death in p53-deficient CCRF - CEM leukemia cells

To determine how p53-deficient CEM human leukemia cells respond to ionizing radiation, we exposed CEM$\mathrm{C} 7 \mathrm{H} 2$ cells to various doses of gamma irradiation. Subsequently, the cells were cultured for up to $96 \mathrm{~h}$ and subjected to determination of apoptosis by fluorescence activated cell sorter (FACS) analyses of propidium iodidestained nuclei. As shown in Figure 1, gamma irradiation 
caused cell death in these cells in a time and dosedependent fashion. Thus, $0.75-1.5 \mathrm{~Gy}$ failed to induce significant apoptosis, 3-12 Gy led to about half-maximal to maximal apoptosis between 64-96 h while 24-96 Gy had killed significant numbers of cells already after $18 \mathrm{~h}$ and reached maximal levels of cell death soon thereafter.

In p53 wild type cells, irradiation causes arrest in the G1 phase of the cell cycle through transcriptional induction of the cyclin-dependent kinase inhibitor p21/WAF1 (ElDeiry et al, 1993; Dulic et al, 1994) and other mechanisms (Smith et al, 1994). To assess a possible effect of irradiation on cell cycle progression in the absence of functional p53, we subjected the gamma irradiated CEM$\mathrm{C} 7 \mathrm{H} 2$ cells shown in Figure 1 to FACS cell cycle analysis. At 1.5-6 Gy, the cells arrested in the G2/M phase of the cell cycle about $12-18 \mathrm{~h}$ after irradiation, with percentages directly proportional to the intensity of irradiation (Figure 2). The G2/M arrest did not appear to be irreversible as part of the cells re-entered the cell cycle as suggested by the reappearance of a G1 peak within the subsequent $12-24 \mathrm{~h}$ (exemplified in Figure 3). Nevertheless, another $24-48 \mathrm{~h}$ later, the majority of cells treated with 3-6 Gy succumbed to death (Figure 1). In cells treated with 24-96 Gy, significant cell death occurred already after $12 \mathrm{~h}$. Since it takes these unsynchronized cells $12-18 \mathrm{~h}$ to accumulate in a particular phase of the cell division cycle, possible effects on the cell cycle were obscured by the early cell death. Cells treated with 12 Gy showed an intermediate phenotype, i.e., after $18 \mathrm{~h}$ some cells had already undergone apoptosis (Figure 1) while about $50 \%$ had arrested in the G2/M phase (not shown).

\section{Gamma irradiation induced cell death in p53-deficient CCRF-CEM cells reveals typical features of apoptosis}

To ascertain that the observed cell death reflected typical apoptosis, irradiated $\mathrm{CEM}-\mathrm{C} 7 \mathrm{H} 2$ cells were investigated by terminal deoxynucleotidyl transferase-mediated dUTP nick end-labeling (TUNEL), Annexin V-staining and electron microscopy. As exemplified in Figure 4, TUNEL gave similar results as propidium iodide-staining, supporting the notion that cell death observed by the latter method was indeed apoptosis. This conclusion was further corroborated by the Annexin $V$ method that, as expected, detected apoptosis several hours earlier than the propidium iodidestaining protocol (see last Results paragraph, Figure 9). Electron microscopy further revealed ultrastructural changes of the irradiated cells characteristic for apoptosis (Figure 5).

\section{Expression of Bcl-2 and Bax are not detectably altered during irradiation-induced apoptosis of CEM-C7H2 cells}

$\mathrm{Bcl}-2$ protects various cell types from cell death induced by different apoptosis inducers including irradiation (Sentman et al, 1991; Strasser et al, 1991; Yin et al, 1994; Cory, 1995; Reed et al, 1996), possibly by regulating release of cytochrome $\mathrm{c}$ and apoptosis inducing factor from mitochondria (Kluck et al, 1997; Kroemer, 1997). To determine whether irradiation-induced apoptosis in our system is associated with, and perhaps caused by, reduction in $\mathrm{Bcl}-2$ expression, we used Western blot analysis (Figure 6) to determine Bcl-2

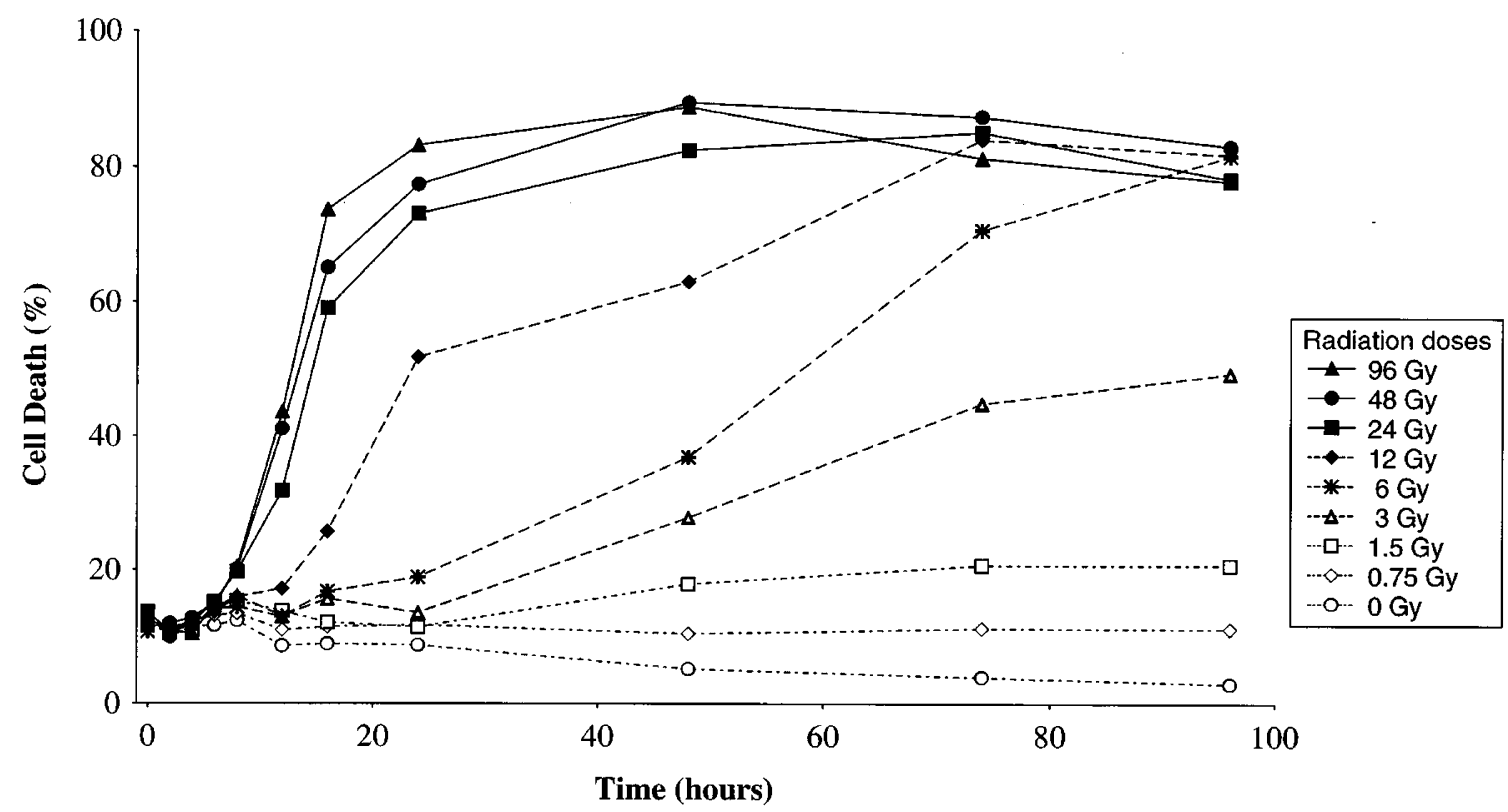

Figure 1 Radiation-induced cell death. CEM-C7H2 cells were irradiated with 0-96 Gy as indicated by the various symbols, cultured for up to $96 \mathrm{~h}$, and apoptosis determined by propidium iodide-staining and FACS analysis 


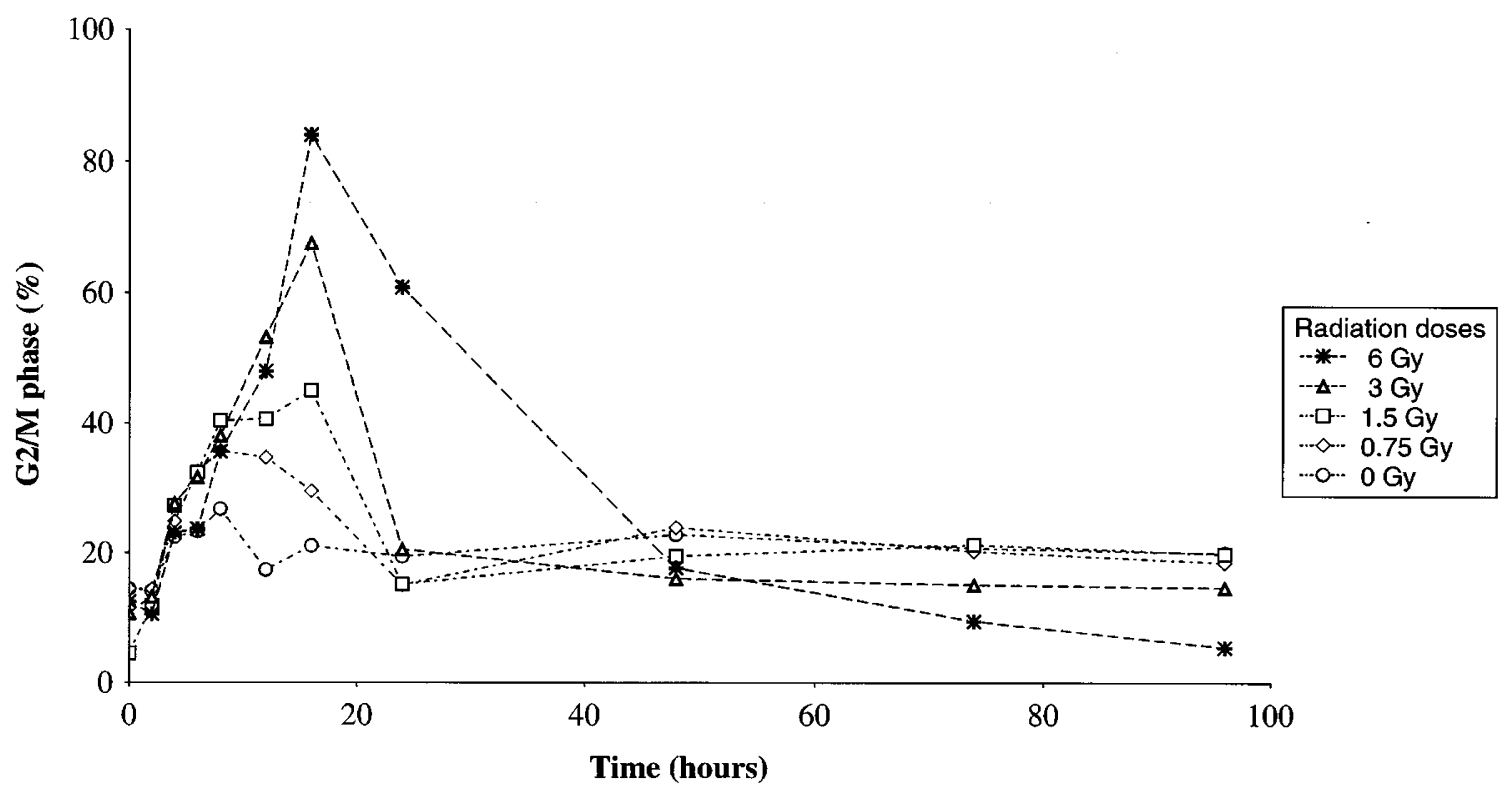

Figure 2 Radiation-induced G2/M cell cycle arrest. CEM-C7H2 cells were irradiated with $0-6$ Gy as indicated by the various symbols, cultured for up to $96 \mathrm{~h}$ and the percentage of cells in the G2/M phase of the cell division cycle determined by propidium iodide-staining and FACS analysis

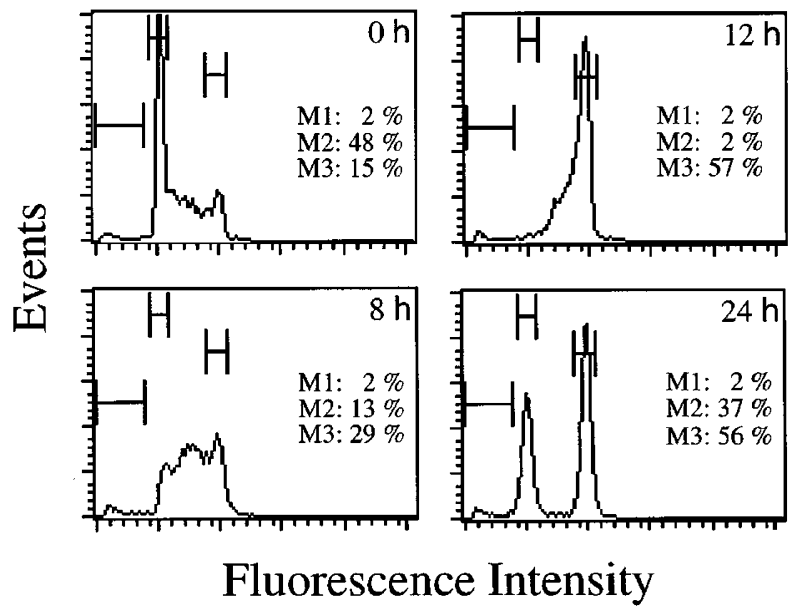

Figure 3 Example of a cell cycle analysis during gamma irradiation. CEM$\mathrm{C} 7 \mathrm{H} 2$ cells were irradiated with $6 \mathrm{~Gy}$ and subjected to cell cycle determination by propidium iodide-staining and FACS analysis after the time points indicated. The percentages of nuclei corresponding to apoptotic cells (marker window M1, sub-G1 peak) and cells in the G1 (marker window M2) or G2/M (marker window M3) phase of the cell division cycle are indicated in each panel

levels in $\mathrm{CEM}-\mathrm{C} 7 \mathrm{H} 2$ leukemia cells exposed to apoptosisinducing levels of gamma irradiation. However, no reduction in $\mathrm{Bcl}-2$ expression was detected. Since overexpression of the $\mathrm{Bcl}-2$ antagonist Bax might equally account for cell death (Oltvai and Korsmeyer, 1994), we investigated expression of its mRNA in irradiated $\mathrm{CEM}-\mathrm{C} 7 \mathrm{H} 2$ cells. As shown in Figure 7, Bax mRNA was, however, not detectably increased in irradiated $\mathrm{CEM}-\mathrm{C} 7 \mathrm{H} 2$ cells. Thus, as far as the two investigated members of the Bcl-2 family were concerned, disturbance of the 'Bcl-2 rheostat' did not seem to be responsible for irradiation-induced cell death in this system.

\section{Functional p53 only marginally increases sensitivity of CCRF-CEM cells to gamma irradiation-induced apoptosis}

To investigate whether functional p53 affects the radiosensitivity of CEM cells, we employed three $\mathrm{CEM}-\mathrm{C} 7 \mathrm{H} 2$ subclones (C7H2-4G5, 3E12, 3H3) that constitutively express a temperature-sensitive p53 mutant (p53ts) (Geley et al, 1997a). When cultured at the permissive temperature $\left(32^{\circ} \mathrm{C}\right)$, these cells expressed significant levels of the p53regulated $\mathrm{p} 21 / \mathrm{WAF} 1$ protein (Figure 8), supporting the functionality of the transfected p53. Although p53 induces apoptosis in these cells (Geley et al, 1997a; and Figure 9), Bcl-2 was not detectably altered (Figure 8), similar to the situation in irradiation-induced apoptosis in the absence of functional p53 (see previous paragraph, Figure 6). Parental $\mathrm{C} 7 \mathrm{H} 2$ and the p53ts-transfected subclones were irradiated, cultured at $37^{\circ} \mathrm{C}$ or $32^{\circ} \mathrm{C}$, and subsequently analyzed for development of apoptosis by the Annexin $\mathrm{V}$ and propidium iodide methods (Figure 9). All cells were about equally sensitive to irradiation at $37^{\circ} \mathrm{C}$ and as expected from our previous time course studies (Geley et al, 1997a), up to $14 \mathrm{~h}$ at the permissive temperature $\left(32^{\circ} \mathrm{C}\right)$ did not yet entail significant levels of apoptosis in the non-irradiated p53tstransfected $\mathrm{C} 7 \mathrm{H} 2$ cells. However, when p53ts-transfected $\mathrm{C} 7 \mathrm{H} 2$ subclones were irradiated and cultured at $32^{\circ} \mathrm{C}$, they underwent higher degrees of apoptosis than non-irradiated cells at $32^{\circ} \mathrm{C}$ or irradiated cells cultured at $37^{\circ} \mathrm{C}$ suggesting that functional p53 increased the sensitivity of these cells to gamma irradiation (exemplified in Figure 9). However, this increase, although consistently detectable, was sometimes only a few percent and never exceeded $50 \%$ by much supporting the concept that the p53-independent pathway to irradiation-induced cell death functions quite efficiently in these leukemia cells. 
TUNEL
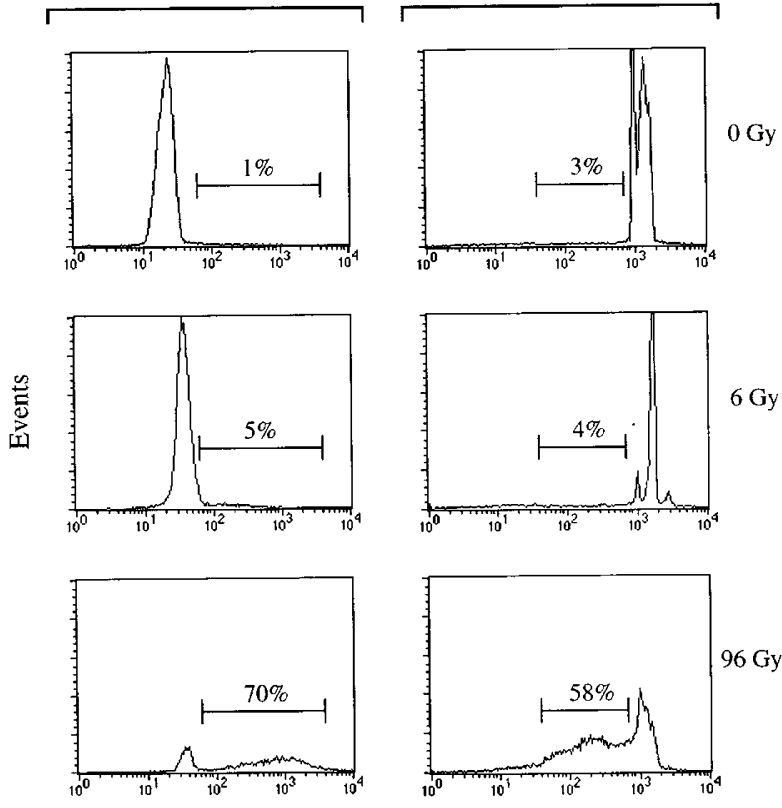

Fluorescence intensity

Figure 4 TUNEL and propidium iodide (PI) methods detect similar levels of apoptosis. CEM-C7H2 cells were exposed to 0,6 or 96 Gy, cultured for $24 \mathrm{~h}$ and subjected to determination of apoptotic cells by the TUNEL and PI methods. The percentages of apoptotic cells are indicated above the marker windows

The present study shows that CCRF-CEM cells, like many other cell types (Strasser et al, 1994; Bracey et al, 1995; Allday et al, 1995; MacFarlane et al, 1996), are equipped with a p53-independent gamma irradiationtriggered cell death pathway. How this pathway relates to the p53-dependent death pathway on a mechanistic and molecular level is not well understood. While irradiation in p53 wild type cells often causes G1 arrest (Dulic et al, 1994; Allday et al, 1995; Pellegata et al, 1996), we observed that, in the absence of functional p53, this treatment leads to increased numbers of cells in the G2/M phase of the cell division cycle. Similar observations were made by us in CCRF-CEM cells treated with the DNA-damaging compound doxorubicin (Geley et al, 1997a) and by others in other systems (Allday et al, 1995; Kan et al, 1995) supporting the notion that DNA-damage in the absence of functional p53 activates a checkpoint at the G2/M transition. Regarding the molecules transmitting the death signals, activation of p53 by irradiation causes transcriptional repression of bcl-2 and induction of bax gene expression (Reed et al, 1996). Bcl-2 mRNA downregulation has also been observed during irradiation-induced death of U937 and HL-60 human leukemia cells (Chen et al, 1995) that are p53-deficient (Danova et al, 1990; Dou et al, 1995). CCRF-CEM cells behaved differently in this respect, because Bcl-2 levels were unaltered during irradiation-triggered, p53-independent apoptosis (Figure 6). However, Bcl-2 was also not regulated during apoptosis induced by functional p53 (Figure 8), hence, the unresponsiveness of $\mathrm{Bcl}-2$ levels to these

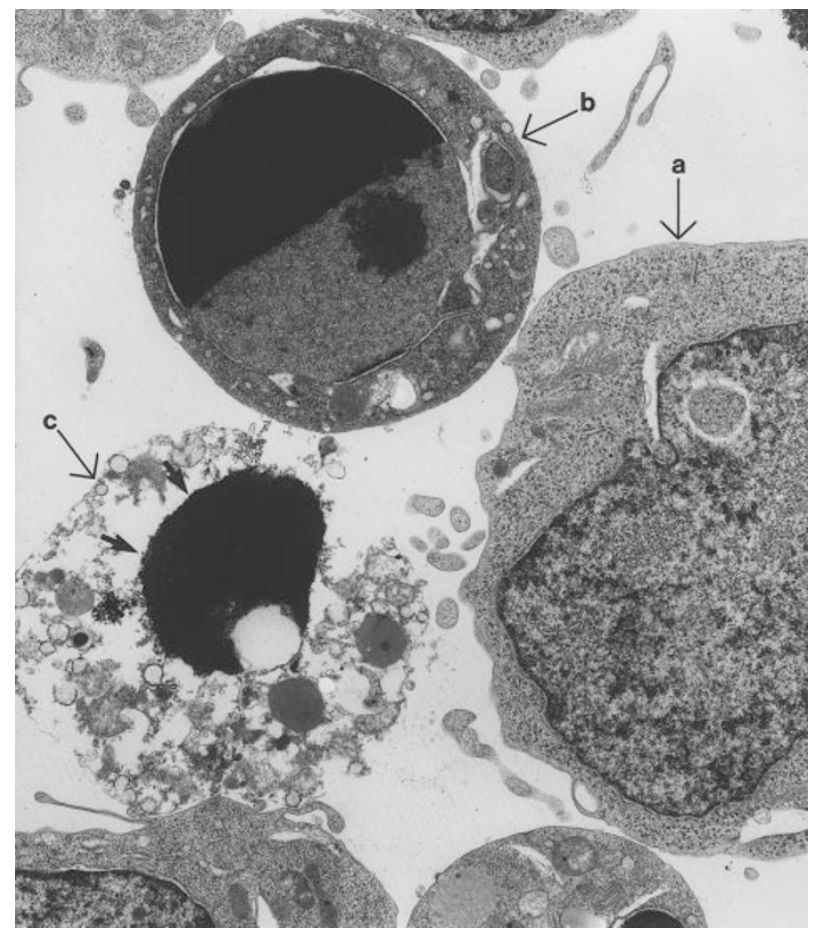

Figure 5 Electron microscopic appearence of irradiated $\mathrm{CEM}-\mathrm{C} 7 \mathrm{H} 2$ cells. CEM-C7H2 cells were exposed to $96 \mathrm{~Gy}$, cultured for $8 \mathrm{~h}$ and subjected to transmission electron microscopy. Cell 'a' resembles a normal lymphocytes of the control samples. Cell 'b' exhibits typical features of apoptosis (condensed chromatin in a semilunar arrangement within the nuclear space; intact cytoplasmic membrane). Lymphocyte ' $c$ ' reveals typical apoptotic features (condensed chromatin, arrows) and in addition a massive destruction of all cellular components, typical for late apoptotic cells. Magnification $\times 11.220$

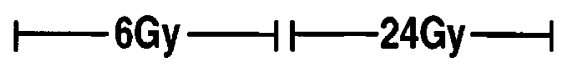

\section{2h 8h 24h 4h $8 \mathrm{~h} \quad 24 \mathrm{~h}$ Co}

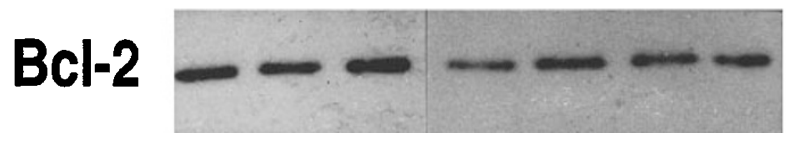

Figure 6 Irradiated $\mathrm{CEM}-\mathrm{C} 7 \mathrm{H} 2$ cells do not downregulate $\mathrm{Bcl}-2$ expression. $\mathrm{CEM}-\mathrm{C} 7 \mathrm{H} 2$ cells were exposed to 0,6 or $24 \mathrm{~Gy}$, cultured for the indicated time, and subjected to Western blot analysis using a monoclonal antibody to $\mathrm{Bcl}-2$

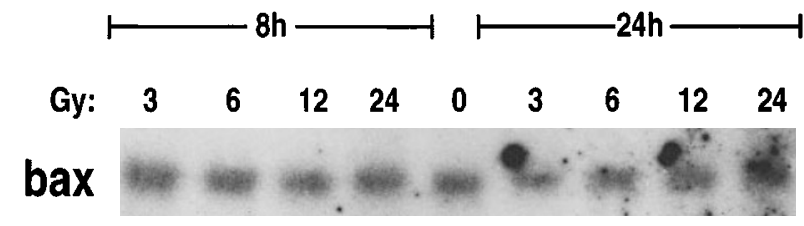

Figure 7 Irradiated $\mathrm{CEM}-\mathrm{C} 7 \mathrm{H} 2$ cells do not upregulate Bax mRNA expression. CEM-C7H2 cells were exposed to $0,3,6,12$ or $24 \mathrm{~Gy}$, cultured for $8 \mathrm{~h}$ or $24 \mathrm{~h}$ and subsequently subjected to Northern blot analysis using a ${ }^{32}$ P-labeled cDNA probe for mouse bax 
apoptosis inducing stimuli may be specific for T-cell leukemia or for this particular cell line. Bax mRNA expression was also not detectably altered in the course of p53-independent irradiation-induced apoptosis (Figure 7),

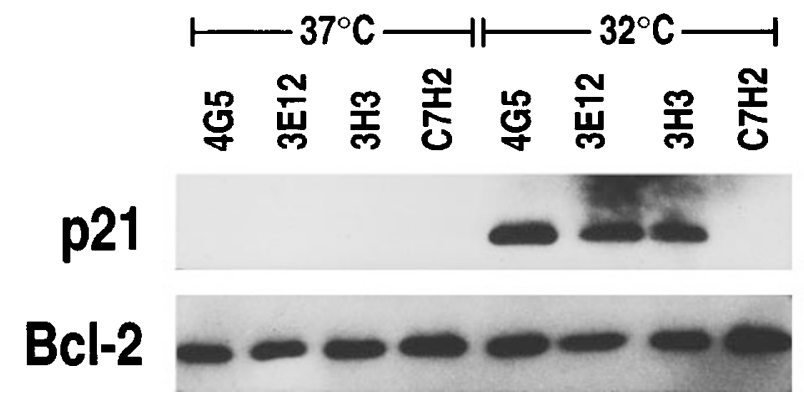

Figure 8 p53 induces p21/WAF1 but has no effect upon Bcl-2 expression in p53ts expressing CEM-C7H2 subclones. Parental CEM-C7H2 and p53tstransfected subclones $4 \mathrm{G} 5,3 \mathrm{E} 12$ and $3 \mathrm{H} 3$ were cultured at $37^{\circ} \mathrm{C}$ or at $32^{\circ} \mathrm{C}$ (the permissive temperature for $\mathrm{p} 53 \mathrm{ts}$ ) for $14 \mathrm{~h}$ and subjected to Western blot analysis using a monoclonal antibody to p21/WAF1 although we previously noted a weak induction of bax mRNA in association with p53-mediated apoptosis in p53ts expressing CCRF-CEM cells (Geley et al, 1997a) suggesting a possible difference in the pathways to p53dependent and independent cell death. Whether other members of the growing $\mathrm{Bcl}-2$ family are involved in p53independent irradiation-induced apoptosis remains to be analyzed.

\section{Material and Methods}

\section{Cell lines and gamma irradiation}

Cell culture conditions, the $\mathrm{CEM}-\mathrm{C} 7 \mathrm{H} 2$ cell line (Strasser-Wozak et al, 1995), and the $\mathrm{C} 7 \mathrm{H} 2$ subclones 4G5, 3E12 and 3H3 (Geley et al, 1997a) that are stably transfected with plasmid pLTRp53V135 (Yonish-Rouach et al, 1991) have been described previously. Proliferating CEM cells $\left(1 \times 10^{6} / \mathrm{ml}\right)$ were irradiated $(0.75-96 \mathrm{~Gy}, 8.7 \mathrm{~Gy} / \mathrm{min})$ in one dose with a gamma source (IBL 437C, ORIS Industry, GIF sur Yvette, France) and subsequently cultured for various time points as indicated in the Results section.

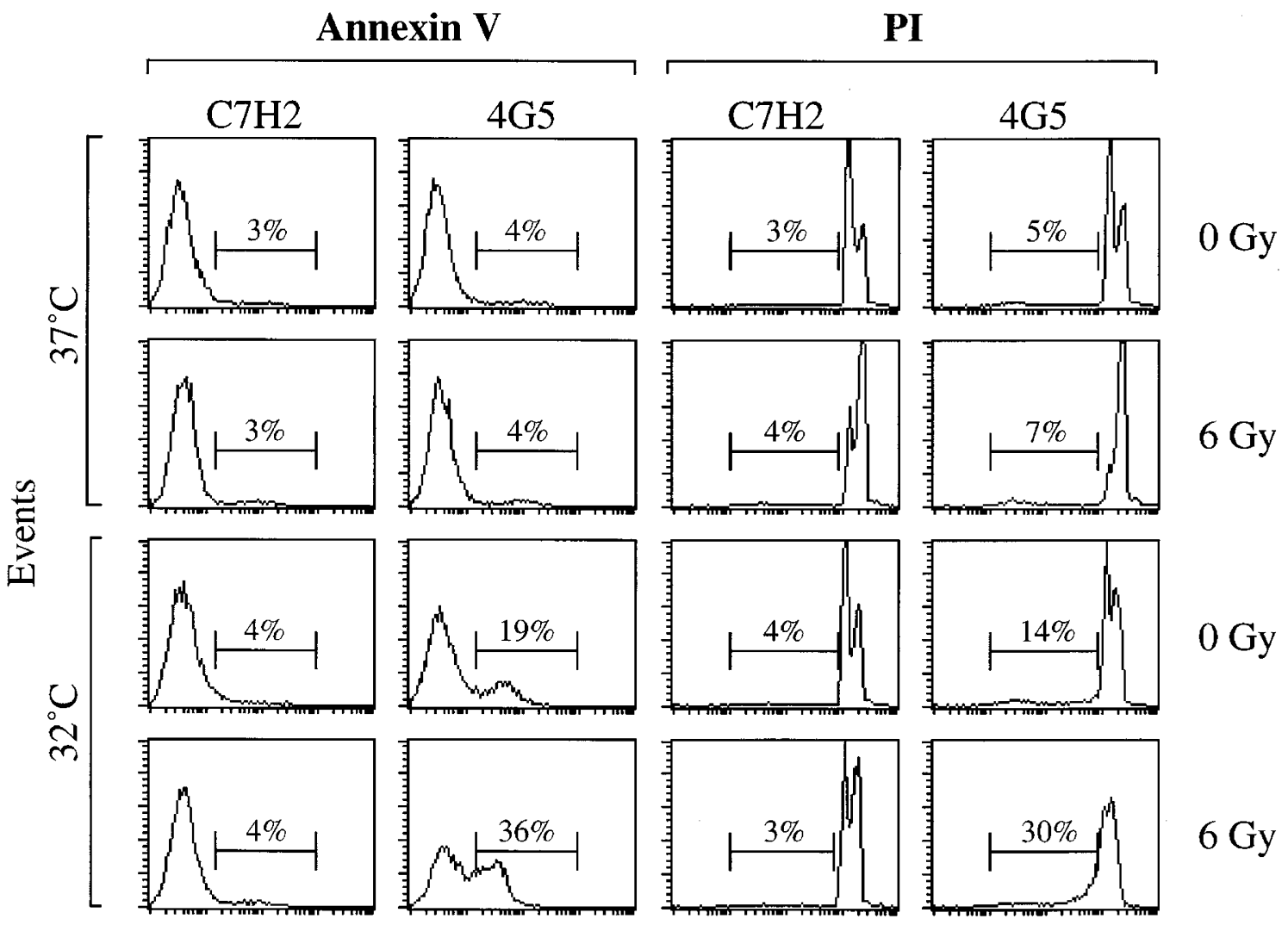

Fluorescence Intensity

Figure 9 Functional p53 cooperates with gamma irradiation to induce apoptosis in $\mathrm{CEM}-\mathrm{C} 7 \mathrm{H} 2$ cells. $\mathrm{CEM}-\mathrm{C} 7 \mathrm{H} 2$ subclones stably transfected with a temperature sensitive p53 mutant (p53ts) and the parental CEM-C7H2 line were exposed to 0 or 6 Gy and cultured for $8 \mathrm{~h}$ (cells subjected to Annexin $\mathrm{V}$ analysis) or $14 \mathrm{~h}$ (cells analyzed by the propidium iodide/PI method) either at $37^{\circ} \mathrm{C}$, the temperature at which the transfected p53ts mutant is inactive, or at $32^{\circ} \mathrm{C}$, the permissive temperature for p53ts. Subsequently the cells were subjected to apoptosis analysis by the Annexin $\mathrm{V}$ or the PI method. The percentages of apoptotic cells are indicated above the marker windows. Shown are the results obtained with subclone 4G5. Additional experiments with this and the subclones $3 \mathrm{H} 3$ and $3 \mathrm{E} 12$ gave similar results although the cooperative effect was sometimes less apparent than in the example shown 


\section{Determination of apoptosis}

For detection and quantification of apoptosis, four distinct methods were used. DNA-staining with propidium iodide and the TUNEL method have been detailed previously (Geley et al, 1997a). For electron microscopic examination, fixation of the cells was performed in $2.5 \%$ glutaraldehyde buffered to $\mathrm{pH} 7.2$ in $0.1 \mathrm{M}$ sodium cacodylate for $2 \mathrm{~h}$ at $4{ }^{\circ} \mathrm{C}$. After an overnight rinse in buffer, the cells were postfixed in $1 \%$ acetate-buffered $\mathrm{OsO}_{4}$ for $2 \mathrm{~h}$, dehydrated in graded series of ethanol and embedded in Epon. Ultrathin sections stained in alcoholic uranyl acetate and alkaline lead citrate were examined in a Philips CM 120. Annexin V binding (Martin et al, 1996) was determined using the TACS Annexin V - FITC kit (TREVIGEN, Gaithersburg, MD) as described by the manufacturer. Briefly, approximately $2.5 \times 10^{5}$ cells were incubated with FITC-labeled Annexin $\mathrm{V}$ and propidium iodide, washed and analyzed on a FACScan as above (forward/ sideward scatter, red and green fluorescence).

\section{Cell cycle analyses}

For cell cycle analyses, the propidium iodide method of Nicoletti et al (1991) was used. To gate out cell doublets, dot plot analysis was additionally conducted in FL3-Width/FL3-Area and fluorescence intensity was plotted on a linear rather than a logarithmic scale.

\section{Western and Northern blot analyses}

$\mathrm{Bcl}-2$ and p21/WAF1 Westerns were performed similar as previously described (Geley et al, 1997b) using mouse monoclonal antibodies against human Bcl-2 (Clone 124, Genosys, London, UK) or human p21/WAF1 (Clone 70, Transduction Laboratories, Lexington, KY) followed by horseradish peroxidase-labeled anti-mouse IgG antibody (Southern Biotechnology Association, Birmingham, AL), and developed using the enhanced chemiluminescence technique (Amersham, Buckinghamshire, UK). Northern analyses were performed as previously detailed (Geley et al, 1996) using heat-denatured ${ }^{32} \mathrm{P}$ labeled mouse bax or humna $\alpha$-tubulin cDNA probes, respectively (kindly provided by Drs S.J. Korsmeyer and A. Helmberg, respectively).

\section{Acknowledgements}

The authors thank DrP. Lukas for providing the irradiation device, Drs A. Helmberg and S.J. Korsmeyer for donating CDNA probes, Dr. P. Debagge for editing the manuscript, and S. Lobenwein, I. Jaklitsch, J. Forgo, and R. Haring for excellent technical assistance. Supported by grants from the Austrian Science Fund (P11964-Med and SFB-F002) and the Austrian National Bank (Project 6156).

\section{References}

Allday MJ, Inman GJ, Crawford DH and Farrell PJ (1995) DNA damage in human B cells can induce apoptosis, proceeding from $\mathrm{G}_{1} / \mathrm{S}$ when p53 is transactivation competent and $\mathrm{G}_{2} / \mathrm{M}$ when it is transactivation defective. EMBO J. 14: 4994 5005

Bracey TS, Miller JC, Preece A and Paraskeva C (1995) gamma-radiation-induced apoptosis in human colorectal adenoma and carcinoma cell lines can occur in the absence of wild type p53. Oncogene 10: 2391-2396

Canman CE, Chen C-Y, Lee M-H and Kastan MB (1994) DNA damage responses: p53 induction, cell cycle perturbations, and apoptosis. Cold Spring Harbor Symp. Quant. Biol. 59: 277-286
Chen M, Quintans J, Fuks Z, Thompson C, Kufe DW and Weichselbaum RR (1995) Suppression of $\mathrm{Bcl}-2$ messenger RNA production may mediate apoptosis after ionizing radiation, tumor necrosis factor $\alpha$, and ceramide. Cancer Res. 55: 991 994

Cheng J and Haas M (1990) Frequent mutations in the p53 tumor suppressor gene in human leukemia T-cell lines. Mol. Cell. Biol. 10: 5502-5509

Clarke AR, Purdie CA, Harrison DJ, Morris RG, Bird CC, Hooper ML and Wyllie AH (1993) Thymocyte apoptosis induced by p53-dependent and independent pathways. Nature 362: 849-852

Cory S (1995) Regulation of lymphocyte survival by the BCL-2 gene family. Annu. Rev. Immunol. 13: 513-543

Danova M, Giordano M, Mazzini G and Riccardi A (1990) Expression of p53 protein during cell cycle measured by flow cytometry in human leukemia. Leuk. Res. 14: 417-422

Dou QP, An B and Will PL (1995) Induction of a retinoblastoma phosphatase activity by anticancer drugs accompanies p53-independent $G_{1}$ arrest and apoptosis. Proc. Natl. Acad. Sci. USA 92: 9019-9023

Dulic V, Kaufmann WK, Wilson SJ, Tlsty TD, Lees E, Harper JW, Elledge SJ and Reed SI (1994) p53-dependent inhibition of cyclin-dependent kinase activities in human fibroblasts during radiation-induced G1 arrest. Cell 76: 1013-1023

El-Deiry WS, Tokino T, Velculescu VE, Levy DB, Parsons R, Trent JM, Lin D, Mercer WE, Kinzler KW and Vogelstein B (1993) WAF1, a potential mediator of p53 tumor suppression. Cell 75: 817-825

Geley S, Hartmann BL, Hala M, Strasser-WozakEMC, KapelariKand Kofler R(1996) Resistance to glucocorticoid-induced apoptosis in human T-cell acute lymphoblastic leukemia CEM-C1 cells is due to insufficient glucocorticoid receptor expression. Cancer Res. 56: 5033-5038

Geley S, Hartmann BL, Hattmannstorfer R, Löffler M, Ausser-lechner MJ, Bernhard D, Sgonc R, Strasser-Wozak EMC, Ebner M, Auer B and Kofler R (1997a) P53induced apoptosis in the human T-ALL cell line CCRF-CEM. Oncogene 15: 2429-2437

Geley S, Hartmann BL, Kapelari K, Egle A, Villunger A, Heidacher D, Greil R, Auer B and Kofler R (1997b) The interleukin $1 \beta$-converting enzyme inhibitor crmA prevents Apo1/fas- but not glucocorticoidinduced poly(ADP-ribose) polymerase cleavage and apoptosis in lymphoblastic leukemia cells. FEBS Lett. 402: $36-40$

Imamura J, Miyoshi I and Koeffler HP (1994) p53 in hematologic malignancies. Blood 84: $2412-2421$

Kan ZY, Chatterjee D, He DM, Early J, Pantazis P, Wyche JH and Hendrickson EA (1995) Evidence for $a G_{2}$ checkpoint in p53-independent apoptosis induction by X-irradiation. Mol. Cell. Biol. 15: 5849-5857

Kluck RM, Bossy-Wetzel E, Green DR and Newmeyer DD (1997) The release of cytochrome $\mathrm{c}$ from mitochondria: A primary site for $\mathrm{Bcl}-2$ regulation of apoptosis. Science 275: $1132-1136$

Komarova EA, Chernov MV, Franks R, Wang KH, Armin G, Zelnick CR, Chin DM, Bacus SS, Stark GR and Gudkov AV (1997) Transgenic mice with p53responsive lacZ: P53 activity varies dramatically during development and determines radiation and drug sensitivity in vivo. EMBO J. 16: 1391-1400

Kroemer G (1997) The proto-oncogene Bcl-2 and its role in regulating apoptosis. Nature Med. 3: 614-620

Lane DP (1992) Cancer: p53, guardian of the genome. Nature 358: 15-16

Lowe SW, SchmittEM, Smith SW, Osborne BA and Jacks T (1993) p53 is required for radiation-induced apoptosis in mouse thymocytes. Nature 362: 847-849

MacFarlane M, Jones NA, Dive C and Cohen GM (1996) DNA-Damaging agents induce both p53-dependent and p53-independent apoptosis in immature thymocytes. Mol. Pharmacol. 50: 900-911

Martin SJ, Reutelingsperger CPM and Green DR (1996) Annexin V: a specific probe for apoptotic cells. In Techniques in apoptosis, In: Cotter TG and Martin SJ, (eds). London: Portland Press Ltd pp. 107-120

Nicoletti I, Migliorati G, Pagliacci MC, Grignani F and Riccardi C (1991) A rapid and simple method for measuring thymocyte apoptosis by propidium iodide staining and flow cytometry. J. Immunol. Methods 139: 271-279

Norman MR and Thompson EB (1977) Characterization of a glucocorticoid-sensitive human lymphoid cell line. Cancer Res. 37: 3785-3791

Oltvai ZN and Korsmeyer SJ (1994) Checkpoints of dueling dimers foil death wishes. Cell 79: 189-192

Pellegata NS, Antoniono RJ, Redpath JL and Stanbridge EJ (1996) DNA damage and p53-mediated cell cycle arrest: A reevaluation. Proc. Natl. Acad. Sci. USA 93: $15209-15214$ 
Prokocimer M and Rotter V (1994) Structure and function of $p 53$ in normal cells and their aberrations in cancer cells: Projection on the hematologic cell lineages. Blood 84: 2391-2411

Reed JC, Miyashita T, Takayama S, Wang HG, Sato T, Krajewski S, Aimé-Sempé C, Bodrug S, Kitada S and Hanada M (1996) BCL-2 family proteins: Regulators of cell death involved in the pathogenesis of cancer and resistance to therapy. J. Cell. Biochem. 60: 23-32

Sentman CL, Shutter JR, Hockenbery D, Kanagawa O and Korsmeyer SJ (1991) Bcl2 inhibits multiple forms of apoptosis but not negative selection in thymocytes. Cell 67: $879-888$

Smith ML, Chen I-T, Zhan Q, Bae I, Chen C-Y, Gilmer TM, Kastan MB, O'Connor PM and Fornace AJ, r. (1994) Interaction of the p53-regulated protein Gadd45 with proliferating cell nuclear antigen. Science 266: $1376-1380$

Strasser A, Harris AW and Cory S (1991) bcl-2 Transgene inhibits T cell death and perturbs thymic self-censorship. Cell 67: 889-899

Strasser A, Harris AW, Jacks T and Cory S (1994) DNA damage can induce apoptosis in proliferating lymphoid cells via p53-independent mechanisms inhibitable by Bcl-2. Cell 79: 329-339
Strasser-Wozak EMC, Hattmannstorfer R, Hála M, Hartmann BL, Fiegl M, Geley S and Kofler R (1995) Splice site mutation in the glucocorticoid receptor gene causes resistance to glucocorticoid-induced apoptosis in a human acute leukemic cell line. Cancer Res. 55: 348-353

Vogelstein B and Kinzler KW (1992) p53 Function and dysfunction. Cell 70:523-526

White E, Chiou S-K, Rao L, Sabbatini P and Lin H-J (1994) Control of p53-dependent apoptosis by E1B, Bcl-2, and Ha-ras proteins. Cold Spring Harbor Symp. Quant. Biol. 59: 395-402

White $E$ (1995) Regulation of p53-dependent apoptosis by E1A and E1B. Curr. Top. Microbiol. Immunol. 199: 33-58

Yin X-M, Oltvai ZN, Veis-Novack DJ, Linette GP and Korsmeyer SJ (1994) Bcl-2 gene family and the regulation of programmed cell death. Cold Spring Harbor Symp. Quant. Biol. 59: 387-394

Yonish-Rouach E, Resnitzky D, Lotem J, Sachs L, Kimchi A and Oren M (1991) Wildtype p53 induces apoptosis of myeloid leukaemic cells that is inhibited by interleukin-6. Nature 352: $345-347$ 